medRxiv preprint doi: https://doi.org/10.1101/2020.06.14.20130740; this version posted June 16, 2020. The copyright holder for this preprint (which was not certified by peer review) is the author/funder, who has granted medRxiv a license to display the preprint in perpetuity.

All rights reserved. No reuse allowed without permission.

\title{
Air Quality and COVID-19 Prevalence/Fatality
}

Hisato Takagi, M.D., Ph.D., Shizuoka Medical Center, Shizuoka, Japan; Kitasato University School of Medicine, Sagamihara, Japan

Toshiki Kuno, M.D., Ph.D., Mount Sinai Beth Israel Medical Center, New York, NY, USA

Yujiro Yokoyama, M.D., Easton Hospital, Easton, PA, USA

Hiroki Ueyama, M.D., Mount Sinai Beth Israel Medical Center, New York, NY, USA

Takuya Matsushiro, M.D., Shizuoka Medical Center, Shizuoka, Japan; Kitasato University School of Medicine, Sagamihara, Japan

Yosuke Hari, M.D., Shizuoka Medical Center, Shizuoka, Japan; Kitasato University School of Medicine, Sagamihara, Japan

Tomo Ando, M.D., New York Presbyterian Hospital/Columbia University Medical Center, New York, NY, USA 
medRxiv preprint doi: https://doi.org/10.1101/2020.06.14.20130740; this version posted June 16, 2020. The copyright holder for this preprint (which was not certified by peer review) is the author/funder, who has granted medRxiv a license to display the preprint in perpetuity.

All rights reserved. No reuse allowed without permission.

\section{Abstract}

To investigate the association of real-time/observed ozone/PM2.5 levels with COVID-19 prevalence/fatality, meta-regression of data from the Northeast megalopolis was conducted. Daily Air Quality Index (AQI) values based on available ozone/PM2.5 data in these counties/cities (3/15/2020-5/31/2020) were extracted from US Environmental Protection Agency and World Air Quality Project. In each county/city, total confirmed COVID-19 cases/deaths (5/31/2020) were available from Johns Hopkins Coronavirus Resource Center, and total population was extracted from US Census Bureau. Randomeffects meta-regression was performed using OpenMetaAnalyst. A meta-regression graph depicted COVID-19 prevalence and fatality (plotted as logarithm-transformed prevalence/fatality on the $y$-axis) as a function of mean ozone/PM2.5 AQI (plotted on the $\mathrm{X}$-axis). Coefficients were not statistically significant for ozone $(\mathrm{P}=0.212 / 0.814$ for prevalence/fatality) and PM2.5 $(\mathrm{P}=0.986 / 0.499)$. Although multivariable analysis had been planned, it was not performed because of non-significant covariates of interest in the univariable model. In conclusion, ozone/PM2.5 may be unassociated with COVID19 prevalence/fatality. 
medRxiv preprint doi: https://doi.org/10.1101/2020.06.14.20130740; this version posted June 16, 2020. The copyright holder for this preprint (which was not certified by peer review) is the author/funder, who has granted medRxiv a license to display the preprint in perpetuity.

\section{Introduction}

Air quality defined by ozone/particulate matter 2.5 (PM2.5)/PM10/CO/SO2/NO2/etc. has been known to affect pulmonary/cardiac diseases. In the recent coronavirus disease 2019 (COVID-19) pandemic, a few studies ${ }^{1-4}$ suggest that air quality also may militate against COVID-19 prevalence/case fatality. To investigate the association of realtime/observed (neither historical nor estimated) ozone/PM2.5 levels with COVID-19 prevalence/fatality, meta-regression (considering a county/city as a study in metaanalysis and weighted by inverse variance of prevalence/fatality) of data from the Northeast megalopolis (including $>50$-million folks, $>15 \%$ of US total population) was conducted.

\section{Methods}

Five Combined Statistical Areas in the Northeast megalopolis comprise 111 counties/cities. Daily Air Quality Index (AQI) values based on available ozone/PM2.5 data in these counties/cities (3/15/2020, beginning of rapid increase of new COVID-19 cases, to 5/31/2020) were extracted from US Environmental Protection Agency (https://www.epa.gov/outdoor-air-quality-data/air-data-daily-air-quality-tracker) and World Air Quality Project (https://aqicn.org/city/usa/newyork/). In each county/city, total confirmed COVID-19 cases/deaths (5/31/2020) were available from Johns Hopkins Coronavirus Resource Center (https://github.com/CSSEGISandData/COVID19/tree/master/csse_covid_19_data/csse_covid_19_daily_reports), and total population 
medRxiv preprint doi: https://doi.org/10.1101/2020.06.14.20130740; this version posted June 16, 2020. The copyright holder for this preprint (which was not certified by peer review) is the author/funder, who has granted medRxiv a license to display the preprint in perpetuity.

All rights reserved. No reuse allowed without permission.

\section{4}

was extracted from US Census Bureau (https://www.census.gov/acs/www/data/datatables-and-tools/data-profiles/). Random-effects meta-regression was performed using OpenMetaAnalyst (http://www.cebm.brown.edu/openmeta/index.html). A metaregression graph depicted COVID-19 prevalence (defined as total cases divided by total population) and fatality (defined as total deaths divided by total cases) (plotted as logarithm-transformed prevalence/fatality on the $y$-axis) as a function of mean ozone/PM2.5 AQI during 3/15/2020-5/31/2020 (plotted on the $\mathrm{x}$-axis).

\section{Results}

Coefficients were not statistically significant for ozone $(P=0.212 / 0.814$ for prevalence/fatality; Fig. 1A/1B) and PM2.5 (P=0.986/0.499; Fig. 1C/1D), which would indicate that COVID-19 prevalence/fatality was unaffected by ozone/PM2.5. Although multivariable analysis had been planned, it was not performed because of non-significant covariates of interest in the univariable model.

\section{Discussion}

The present meta-regression suggests no association of real-time/observed ozone/PM2.5 with COVID-19 prevalence/fatality, which is incompatible with previous findings in

Chinese 3 cities (Wuhan/XiaoGan/HuangGang), ${ }^{1}$ California state, ${ }^{2}$ Milan metropolitan area (Lombardy, Italy), ${ }^{3}$ and Queens county (NY). ${ }^{4}$ Our analysis included far greater 
cases $(>780,000)$ and deaths $(>52,000)$ (among $>48$-million population in the Northeast megalopolis consisting of Boston/New York/Philadelphia/Baltimore/DC/etc.) than these studies. ${ }^{1-4}$

A preliminary study (https://www.medrxiv.org/content/10.1101/2020.04.05.20054502v2) from Harvard University analyzing the largest cases/deaths from $>3,000$ US counties demonstrated that a small increase in PM2.5 was associated with a large increase in fatality. The investigators, however, used long-term (2000-2016)/estimated PM2.5. In the present study, real-time (3/15/2020-5/31/2020)/observed (neither historical nor estimated) ozone/PM2.5 was analyzed.

In conclusion, ozone/PM2.5 may be unassociated with COVID-19 prevalence/fatality, which should be verified by further experimental/clinical/epidemiological investigations.

\section{References}

1. Jiang $\mathrm{Y}, \mathrm{Wu} \mathrm{XJ}$, Guan $\mathrm{YJ}$. Effect of ambient air pollutants and meteorological variables on COVID-19 incidence. Infect Control Hosp Epidemiol 2020 May 11:1-11. doi: 10.1017/ice.2020.222. Epub ahead of print. PMID: 32389157.

2. Bashir MF, Ma BJ, Bilal, et al. Correlation between environmental pollution indicators and COVID-19 pandemic: A brief study in Californian context. Environ Res 2020 May 13;187:109652. doi: 10.1016/j.envres.2020.109652. Epub ahead of print. PMID: 32405084; PMCID: PMC7219392. 
medRxiv preprint doi: https://doi.org/10.1101/2020.06.14.20130740; this version posted June 16, 2020. The copyright holder for this preprint (which was not certified by peer review) is the author/funder, who has granted medRxiv a license to display the preprint in perpetuity.

All rights reserved. No reuse allowed without permission.

\section{6}

3. Zoran MA, Savastru RS, Savastru DM, Tautan MN. Assessing the relationship between surface levels of PM2.5 and PM10 particulate matter impact on COVID-19 in Milan, Italy. Sci Total Environ 2020 Jun 2;738:139825. doi: 10.1016/j.scitotenv.2020.139825. Epub ahead of print. PMID: 32512362; PMCID: PMC7265857.

4. Adhikari A, Yin J. Short-Term Effects of Ambient Ozone, PM2.5, and Meteorological Factors on COVID-19 Confirmed Cases and Deaths in Queens, New York. Int J Environ Res Public Health 2020;17:E4047. 


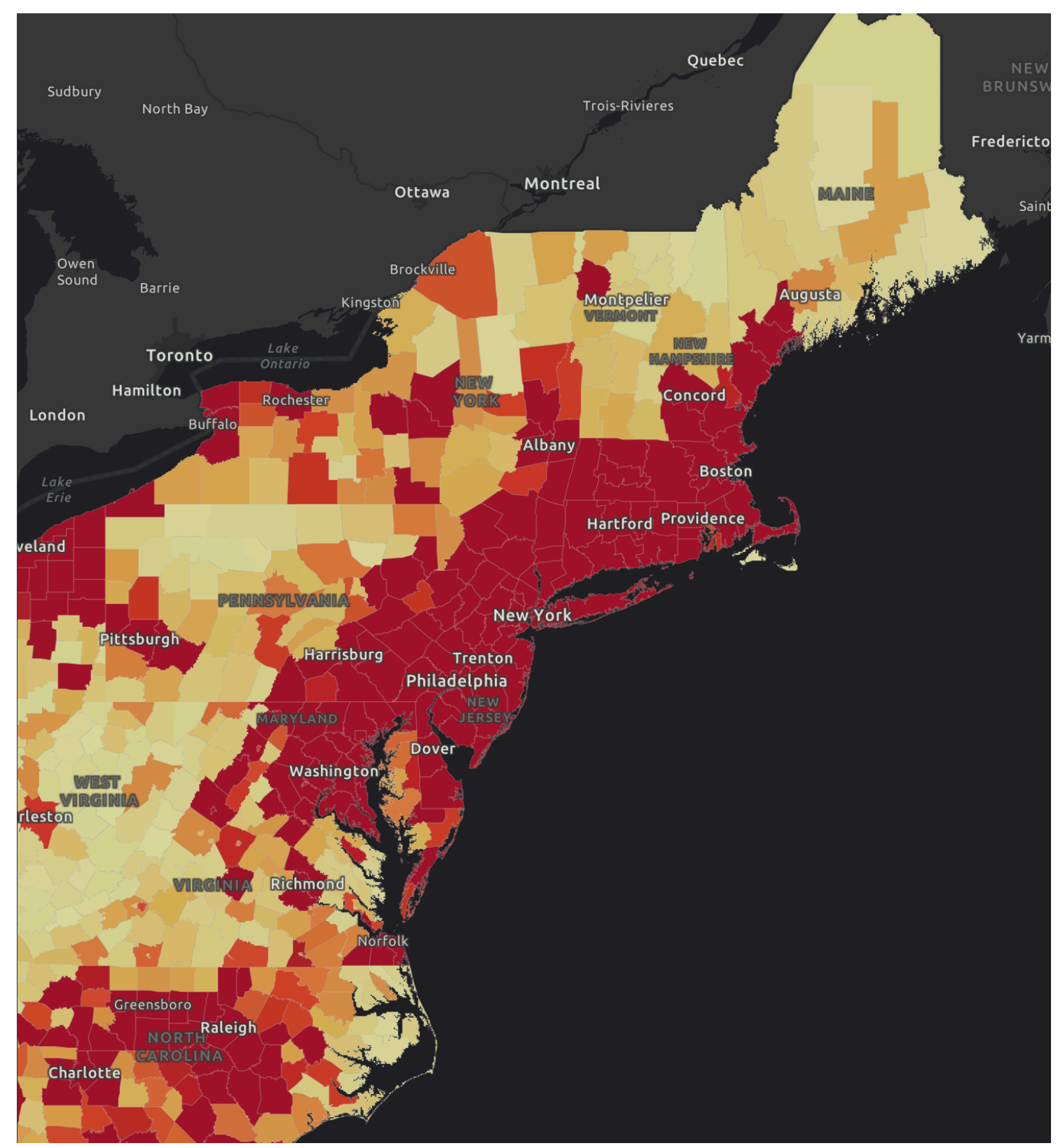

COVID-19 Pandemic in the Northeast Megalopolis (https://coronavirus.jhu.edu/usmap). 
medRxiv preprint doi: https://doi.org/10.1101/2020.06.14.20130740; this version posted June 16, 2020. The copyright holder for this preprint (which was not certified by peer review) is the author/funder, who has granted medRxiv a license to display the preprint in perpetuity.

All rights reserved. No reuse allowed without permission.

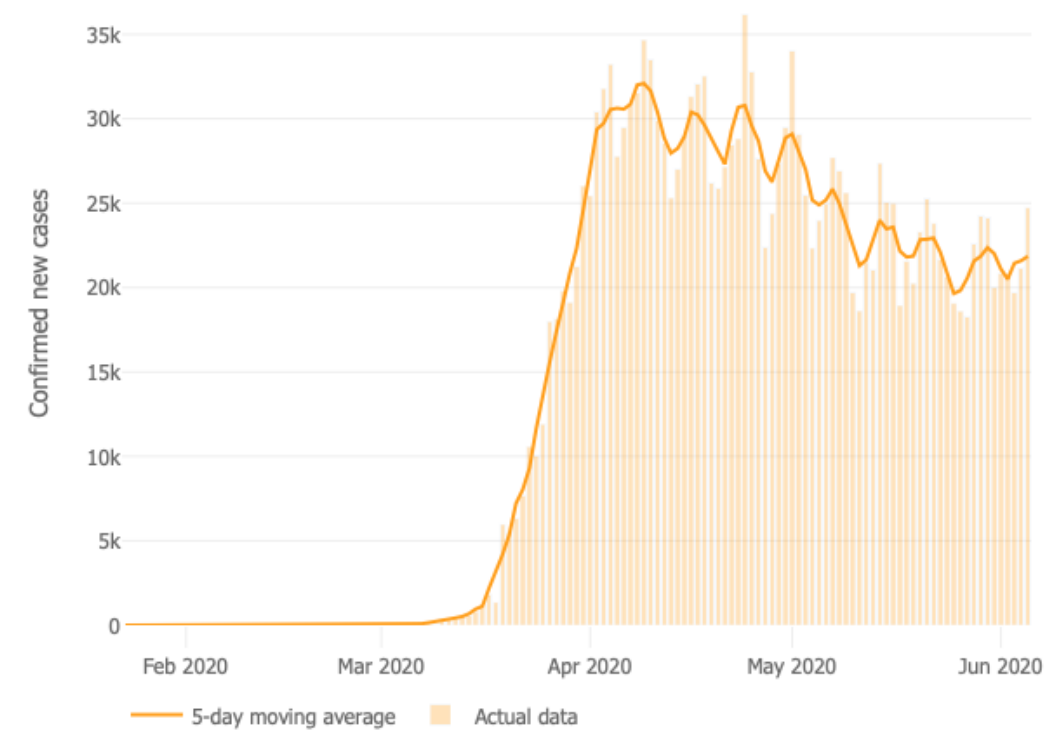

Daily Confirmed New Cases in US (https://coronavirus.jhu.edu/data/new-cases). 
medRxiv preprint doi: https://doi.org/10.1101/2020.06.14.20130740; this version posted June 16, 2020. The copyright holder for this preprint (which was not certified by peer review) is the author/funder, who has granted medRxiv a license to display the preprint in perpetuity.

All rights reserved. No reuse allowed without permission.

A

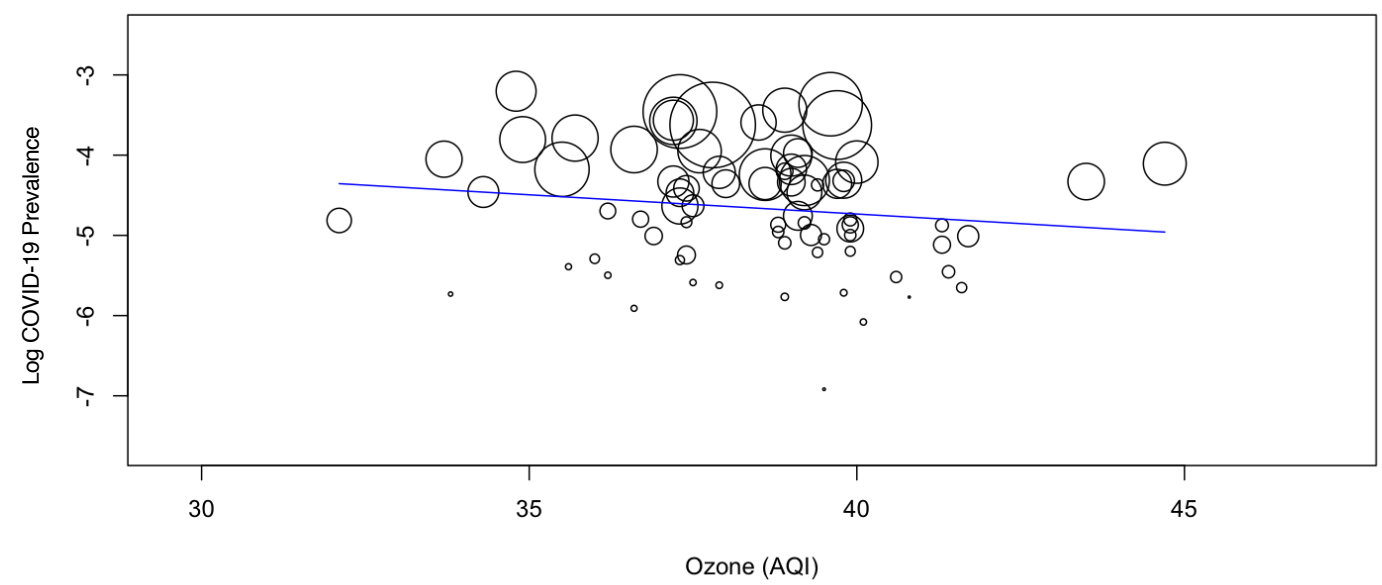

B

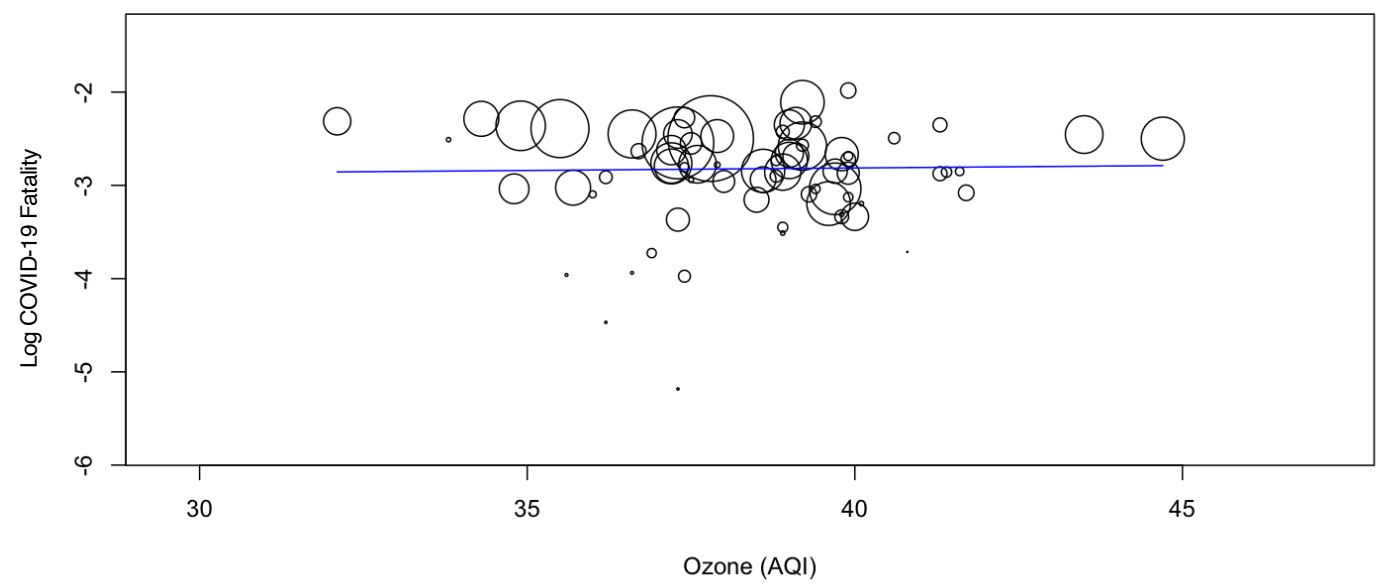


medRxiv preprint doi: https://doi.org/10.1101/2020.06.14.20130740; this version posted June 16, 2020. The copyright holder for this preprint (which was not certified by peer review) is the author/funder, who has granted medRxiv a license to display the preprint in perpetuity.

All rights reserved. No reuse allowed without permission.

C

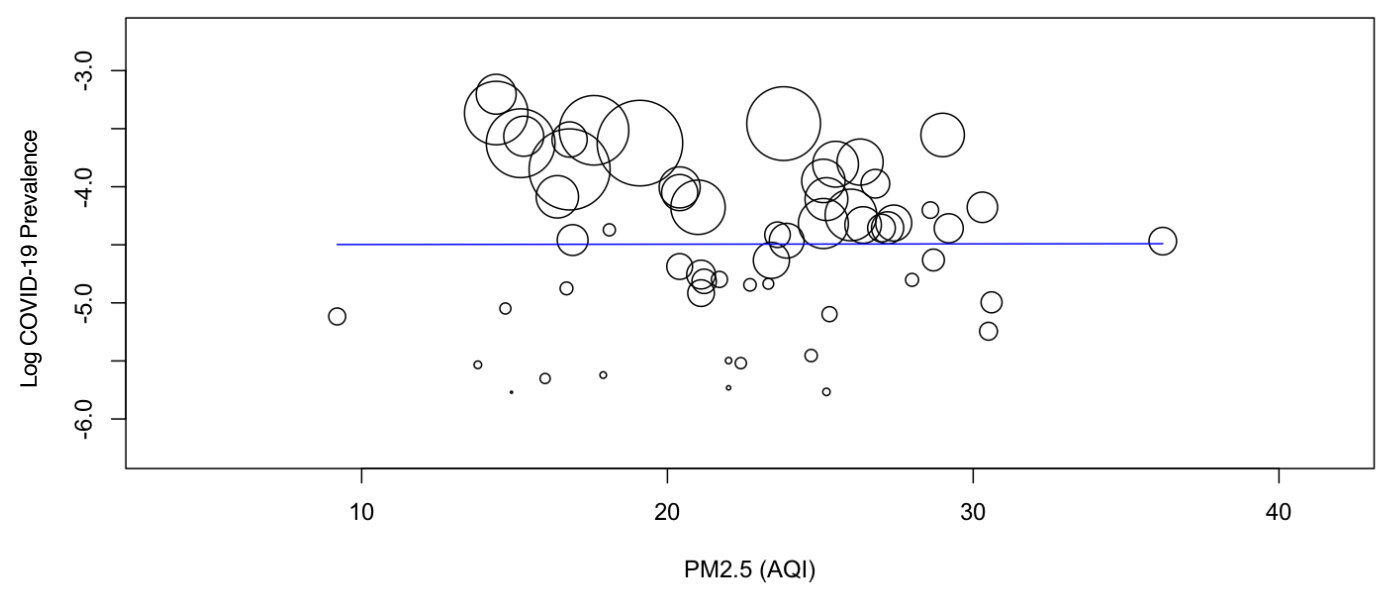

D

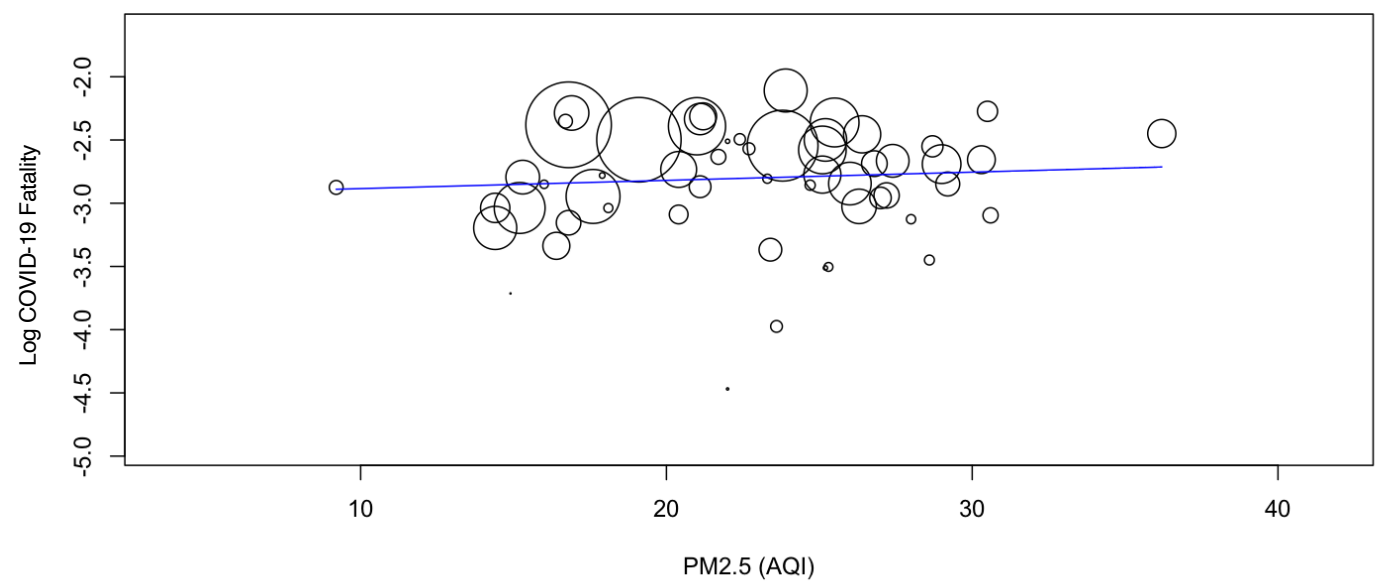

Figure 1. A Meta-Regression Line with Its 95\% Confidence-Interval Curves Depicting the COVID-19 Prevalence/Fatality (Plotted as the LogarithmTransformed Prevalence/Fatality on the Y-Axis) as a Function of Mean Ozone/PM2.5 AQI During 3/15/2020-5/31/2020 (Plotted on the X-Axis). 